\title{
Faktor lingkungan yang mempengaruhi keberadaan hama yang mengganggu penghuni rumah di Kota Pekanbaru
}

\author{
Agus Sutikno $^{1 *}$, Aslim Rasyad ${ }^{2}$, Bintal Amin ${ }^{3}$, Radith Mahatma ${ }^{4}$ \\ 1,2Program Studi Agroteknologi Fakultas Pertanian Universitas Riau \\ ${ }^{3}$ Program Studi Ilmu Kelautan Fakultas Perikanan dan Ilmu Kelautan Universitas Riau \\ ${ }^{4}$ Program Studi Biologi Fakultas Matematika dan Ilmu Pengetahuan Alam Universitas Riau \\ *Korespondensi Email: agus.sutikno@lecturer.unri.ac.id
}

(Diterima 26 Juni 2020|Disetujui 05 Januari 2021|Diterbitkan 30 Januari 2021)

\begin{abstract}
Pests that are often a household problem in several cities in Indonesia are mosquitoes, rats, cockroaches, flies. Causes of settlement pests are dirty environments, food scraps, rubbish, and waterlogged gutters / ditches. The presence of pests in the house causes occupants to control pesticides. Pesticides are used primarily to control mosquitoes, ants, flies, cockroaches, mice and termites. This research is a descriptive research that aims to explain, detail and make a description of a phenomenon or object under study. The target population in this study is households residing in Pekanbaru City, namely in the Districts of Tenayan Raya, Sail and Pekanbaru City with three clean, medium and dirty categories. Determination of the sample is done purposively with multistage sampling technique. The sample was determined purposively with multistage sampling technique and the total sample was 101 households. The data obtained were nominal, ordinal and ratio, analyzed the relationship between these data using chi-square. The results showed that the physical environmental factors of housing settlements that affect the presence of residential pests are dirty environments caused by garbage and dirty drainage / ditches. Meanwhile, biotic environmental factors in residential housing that affect the presence of pests are plants grown in residential areas in the form of ornamental plants and unkempt shade plants. The dirty condition of the residential environment is due to the lack of environmental cleaning activities and the not yet routine transportation of waste from residential homes to landfills. In addition, there is less care for ornamental plants and shade in the yard, such as pruning.
\end{abstract}

\section{Keywords: settlement pests, settlement pest control, environmental factors that affect pests}

Hama permukiman yaitu hewan atau mahluk hidup di sekitar manusia dan permukimannya yang menimbulkan gangguan fisik dan psikis bagi penghuni rumah tangga (Sigit et al., 2006). Keberadaan hewan tersebut mengakibatkan bahaya, kerugian dan gangguan bagi penghuni rumah (Farooq et al., 2010; Kass et al., 2005).

Hama permukiman yang ditemui di rumah adalah semut, dan kecoa (Farooq et al., 2010). Masyarakat Carolina Utara menilai semut dan kecoa merupakan hama utama di permukiman (Dingha et al., 2013). Sementara di New York City, hama permukiman yang utama adalah kecoa (Kass et al., 2005). Hama yang sering menjadi masalah rumah tangga di beberapa kota di Indonesia adalah nyamuk, tikus, kecoak, lalat (Nafis, 2009; Yuliani, 2012; Sutikno et al., 2019a), dan rayap (Sutikno et al., 2019a). Penyebab timbulnya hama permukiman diantaranya lingkungan yang kotor, sisa makanan, sampah, dan selokan/got/parit yang tergenang air (Nafis, 2009). Menurut Scott et al. (2014) habitat lalat umumnya pada tempat yang kotor seperti tempat pembuangan sampah. Lalat berkembang biak pada tinja atau feses, karkas, sampah, limbah buangan (Sigit et al., 2006) dan paling banyak pada kotoran hewan (Arroyo \& Capinera, 2008).

Kondisi lingkungan yang dapat menarik tikus yaitu adanya sampah yang terbuka. Lingkungan rumah yang kotor lebih banyak ditemukan hama tikus dari pada rumah yang bersih (Himsworth et al., 2013). Menurut Gomez et al. (2008) kelimpahan tikus di kota
Rio Cuarto cenderung meningkat terdapat di kawasan yang kotor dan kumuh. Kecoa hidup di tempat kotor yang banyak terdapat sampah pohon dan bahan yang mengandung selulosa (Bell et al., 2007). Tempat yang disukai sebagai sarang hama diantaranya kamar tidur, kamar mandi, dapur, tempat sampah, selokan dan halaman rumah yang kotor (Nafis, 2009).

Keberadaan hama di rumah tersebut menyebabkan penghuni rumah melakukan pengendalian dengan pestisida. Pestisida digunakan utamanya untuk mengendalikan nyamuk, semut, lalat, kecoak, tikus, dan rayap (Grossman, 1995; WHO, 1999). Penggunaan pestisida rumah tangga di India Selatan paling banyak digunakan untuk membunuh nyamuk dan semut (Laksham et al., 2016) dan di California Utara hama yang dikendalikan adalah semut (Guha et al., 2013). Di Indonesia, seperti di DKI Jakarta sebesar 80\% (Raini, 2009) dan Kota Pekanbaru sebesar 92,86\% (Sutikno et al., 2019a). Keadaan ini diperparah, bahwa sebagian besar penggunaannya dilakukan masyarakat dengan tidak benar dan tepat (Sutikno et al., 2019b).

Kondisi lingkungan permukiman (fisik dan biologi) mempengaruhi keberadaan hama di rumah, sehingga mempengaruhi penggunaan pestisida rumah tangga untuk mengendalikan hama. Oleh karena itu, perlu diketahui faktor lingkungan dominan yang mempengaruhi munculnya hama di rumah, sehingga dapat dilakukan upaya untuk menekan keberadaan hama, sehingga penggunaan pestisida oleh penghuni rumah berkurang. 


\section{BAHAN DAN METODE}

Penelitian ini merupakan riset deskriptif yang bertujuan untuk menjelaskan, merinci dan membuat deskripsi terhadap suatu gejala atau objek yang diteliti. Populasi sasaran pada penelitian ini adalah rumah tangga yang bertempat tinggal di Kota Pekanbaru yaitu di Kecamatan Tenayan Raya, Sail dan Pekanbaru Kota dengan tiga kategori bersih, sedang dan kotor. Penentuan sampel dilakukan secara purposive dengan teknik multistage sampling dan jumlah sampel sebanyak 101 rumah tangga.

Penelitian ini deskriptif korelasional dengan mendeskripsikan kondisi hubungan perilaku penghuni rumah tangga terhadap sumber munculnya hama permukiman. Peneliti mencermati secara mendalam terhadap fenomena perilaku penghuni rumah tangga dengan memfokuskan pada faktor lingkungan yang menyebabkan keberadaan hama permukiman yang dianggap menggangu penghuni rumah. Pengambilan data dengan teknik wawancara mendalam dengan menggunakan kuesioner terstruktur dan pengamatan lapangan secara langsung .

Data yang diperoleh bersifat nominal, ordinal dan rasio, dianalisis hubungan antar data tersebut dengan menggunakan chi-square (Singarimbun \& Effendy, 2006).

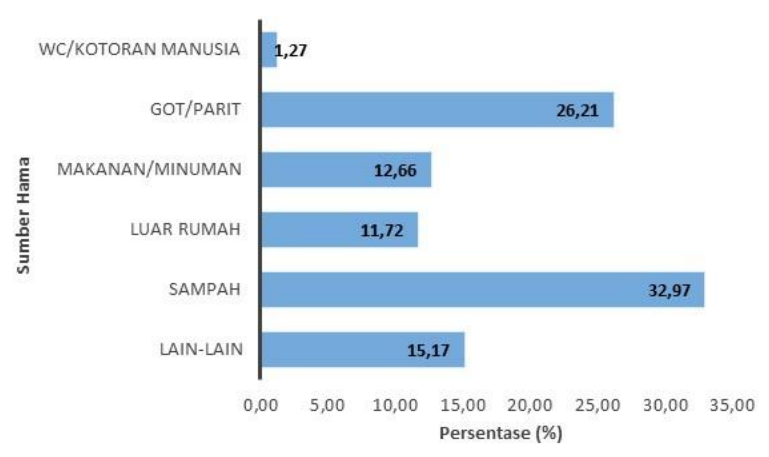

Gambar 1. Persentase persepsi responden terhadap sumber munculnya hama rumah tangga

\section{Kondisi Biologi Permukiman}

Tumbuhan yang ada di permukaan rumah Kota Pekanbaru berdasarkan asalnya terdiri dari tanaman alamiah dan tanaman budidaya. Berdasarkan data BAPPEDA Kota Pekanbaru, (2015), bahwa tanaman alamiah yang terjadi tanpa campur tangan manusia sebagian besar berada di kawasan hutan lindung, yaitu sekitar 8\% dari luas wilayah Kota Pekanbaru. Hasil pengamatan, umumnya jenis tanamannya berupa tanaman keras jenis kayu-kayuan seperti jati, mahoni, angsana, trembesi, gaharu, dan kulim. Selain itu, terdapat tanaman buah-buahan, seperti jambu, durian, cempedak, nangka, dan petai.

Tanaman yang dibudidayakan masyarakat di lokasi penelitian, diperoleh gambaran bahwa sebagian besar permukiman di Kecamatan Sail, Kecamatan Pekanbaru Kota dan Kecamatan Tenayan Raya banyak ditanami tanaman buah di pekarangan dan tanaman pelindung (peneduh) di lingkungannya (Gambar 2).

Pada Gambar 2, jenis tanaman pohon yang banyak ditanam di pekarangan rumah sebanyak $62,32 \%$ berupa jenis tanaman buah-buahan dan $37,68 \%$ tanaman pohon peneduh. Jenis tanaman buah yang ditanam adalah jenis jambu biji, jambu air dan matoa. Kondisi tanaman jambu biji dan jambu air terlihat tidak terawat, jarang dilakukan pembersihan (sanitasi) pada buah yang jatuh ke tanah karena terserang hama atau sudah terlalu masak. Begitu juga pada jenis tanaman matoa. Kondisi ini menyebabkan pekarangan menjadi kotor, sehingga banyak terlihat lalat buah dan lalat rumah berterbangan di areal tanaman jambu tersebut. Keberadaan taman rumah yang rimbun dapat menjadi habitat nyamuk karena kondisi iklim mikro (suhu dan kelembaban udara) mendukung sebagai tempat persembunyian nyamuk. Kondisi suhu dan kelembaban udara mempengaruhi serangga untuk mencari tempat berkembang biak, tempat mencari makan atau tempat berlindung (Speight et al., 2008; Mavi dan Tupper, 2004).

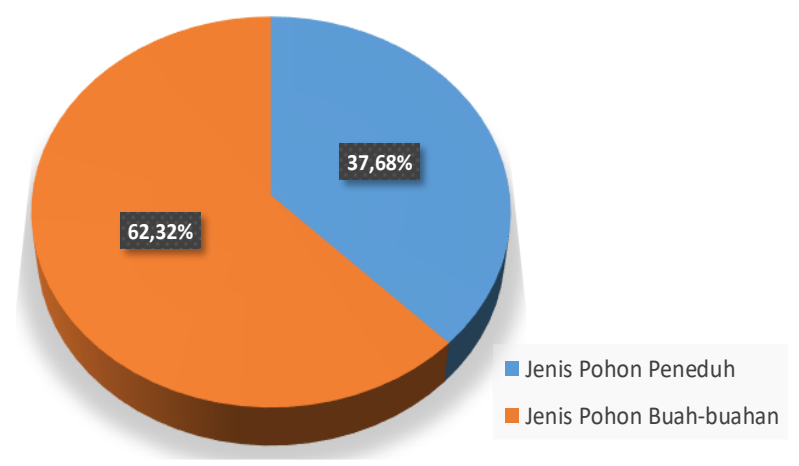

Gambar 2. Proporsi jenis tanaman pohon yang ditanam di pekarangan rumah

Keberadaan tanaman hias di pekarangan rumah bertujuan untuk keindahan agar terlihat asri dan nyaman. Namun banyak tanaman hias yang ada tidak dirawat dengan baik oleh penghuni rumah, sehingga tanaman hias tersebut tidak teratur dan terkesan semak. Tanaman lindung yang ditanam umumnya jenis tanaman hutan seperti mahoni, angsana dan pucuk merah, namun jarang dilakukan perawatan seperti pemangkasan (Gambar 3).

Kondisi lingkungan ini merupakan habitat yang cocok bagi hewan dan hama permukiman baik sebagai tempat tinggal maupun persembunyian. Selain itu, ada tanaman yang hias dan tanaman lindung yang menjorok ke bagian bangunan rumah menjadi sarana bagi hama untuk masuk ke rumah, terutama bagi semut dan tikus. 

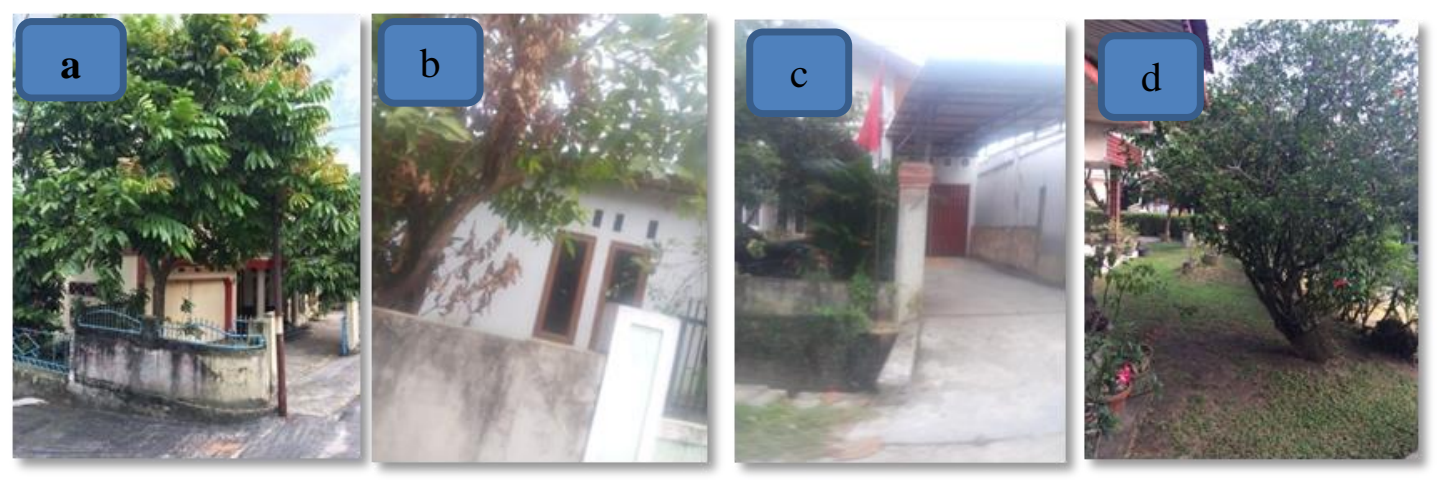

Gambar 3. Kondisi pemukiman yang ditanami tanaman budidaya di beberapa permukiman yang tidak terawat. a dan b. Kelurahan Cinta Raja, Kecamatan Sail, c. Kelurahan Sukamaju, Kecamatan Sail, d. Kelurahan Rejosari, Tenayan Raya, e. Kelurahan Tangkerang Timur, Kecamatan Tenayan Raya.

Selain itu, masyarakat juga menanam jenis tanaman hias yang berpotensi sebagai biopestisida di pekarangan rumahnya. Jenis tanaman melati yang paling banyak ditanam masyarakat $(37,29 \%)$, lavender dan serai masing-masing sebanyak $25,42 \%$, sirih $(10,17 \%)$ dan kemangi sebanyak 1,69\% (Gambar 4). Penggunaan tanaman hias yang berpotensi biopestisida merupakan upaya responden untuk mengurangi gangguan dari hama permukiman, terutama nyamuk. Menurut Kardinan (2007; 2005; 2000) kelima jenis tanaman tersebut merupakan tanaman biopestisida, karena menghasilkan senyawa sekunder (alelokimia) yang menyebabkan penolakan kepada serangga (repelent) (Kardinan, 2007).

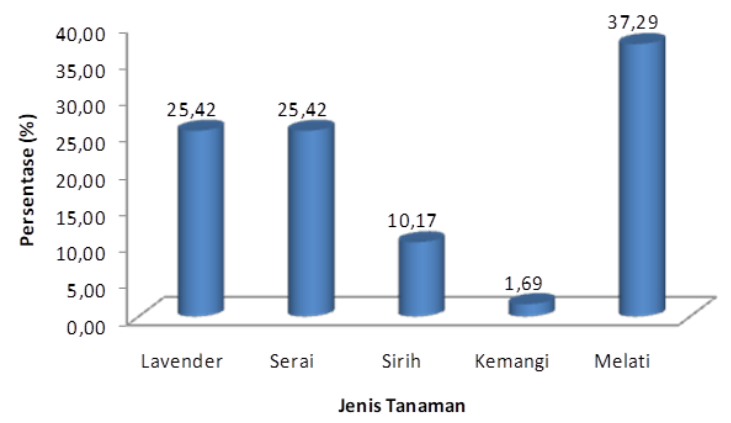

Gambar 4. Jenis tanaman hias berpotensi biopestisida yang ditanam di pekarangan rumah responden

Namun, sebagian besar responden tidak mengetahui tentang biopestisida termasuk jenis tanaman di pekarangan rumah yang dapat berfungsi sebagai pengusir hama. Gambar 5 menunjukkan bahwa sebanyak $70,71 \%$ responden tidak mengetahui atau tidak pernah mendengar tentang biopestisida, hanya $29,29 \%$ responden yang mengakui mengetahui dan pernah mendengar tentang biopestisida. Hasil ini menunjukkan bahwa sedikit sekali informasi kepada masyarakat tentang pengendalian hama selain menggunakan pestisida, terutama tentang Responden menanam beberapa jenis tanaman yang berpotensi biopestisida di pekarangan rumah tersebut sebagai tanaman hias hanya bertujuan sebagai penghias dan kenyamanan saja.

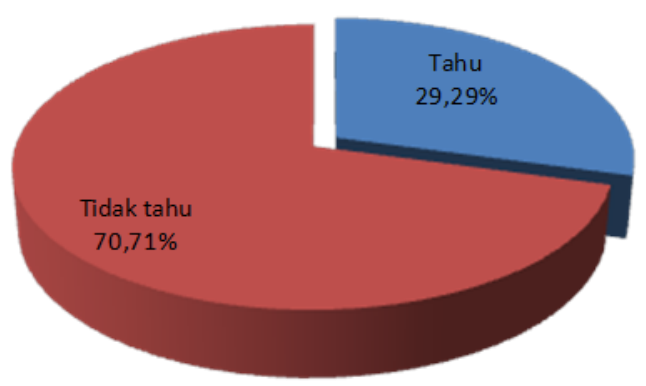

Gambar 5. Persentase pengetahuan responden tentang biopestisida

Faktor biologi lain yang mempengaruhi lingkungan permukiman adalah adanya hewan peliharaan. Hewan peliharaan yang banyak dipeliharan anggota rumah tangga berfungsi sebagai hobby dan penjaga rumahyaitu anjing dan kucing (Gambar 6). Selain itu, hewan peliharaan seperti kucing berfungsi sebagai pengusir/pemakan (predator) hama permukiman seperti tikus. Menurut Untung (2006) \& Oka (2005) kucing merupakan musuh alami (predator) dari hama tikus. Hewan yang banyak dipelihara anggota rumah tangga adalah kucing sebanyak $48,84 \%$ dan ikan hias sebanyak 38,37\% (Gambar 5). Keadaan ini diduga menyebabkan keberadaan hama tikus di permukiman rumah di Kota Pekanbaru relatif kecil berkisar 23,64\% (Sutikno et al., 2020). 


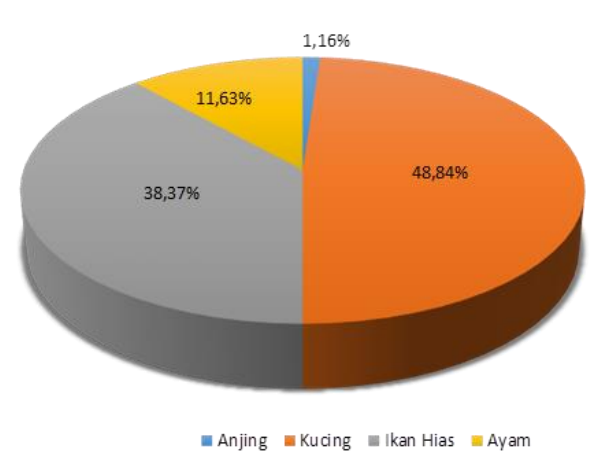

Gambar 6. Persentase jenis hewan yang dipelihara oleh anggota rumah tangga responden

\section{Kondisi Fisik Permukiman}

Kondisi fisik lingkungan permukiman yang mempengaruhi keberadaan hama dilihat dari tatanan kawasan permukiman sarana dan prasarana yang mencakup beberapa aspek, antara lain yaitu pembuangan air limbah rumah tangga, pengelolaan sampah, dan kondisi tempat tinggal.

Hasil pengamatan langsung di lokasi penelitian menggambarkan bahwa kondisi lingkungan fisik permukiman di Kecamatan Pekanbaru Kota, Kecamatan Sail dan Kecamatan Tenayan Raya yaitu banyak kondisi saluran air yang tersumbat. Hal ini disebabkan tiga kawasan tersebut merupakan wilayah yang paling dekat dengan sungai dan kondisinya sangat datar sehingga air tidak lancar mengalir. Kondisi ini diperparah dengan banyaknya sampah yang berada di badan sungai, sampah yang menyebabkan pendangkalan dan penyempitan sungai (Gambar 7).
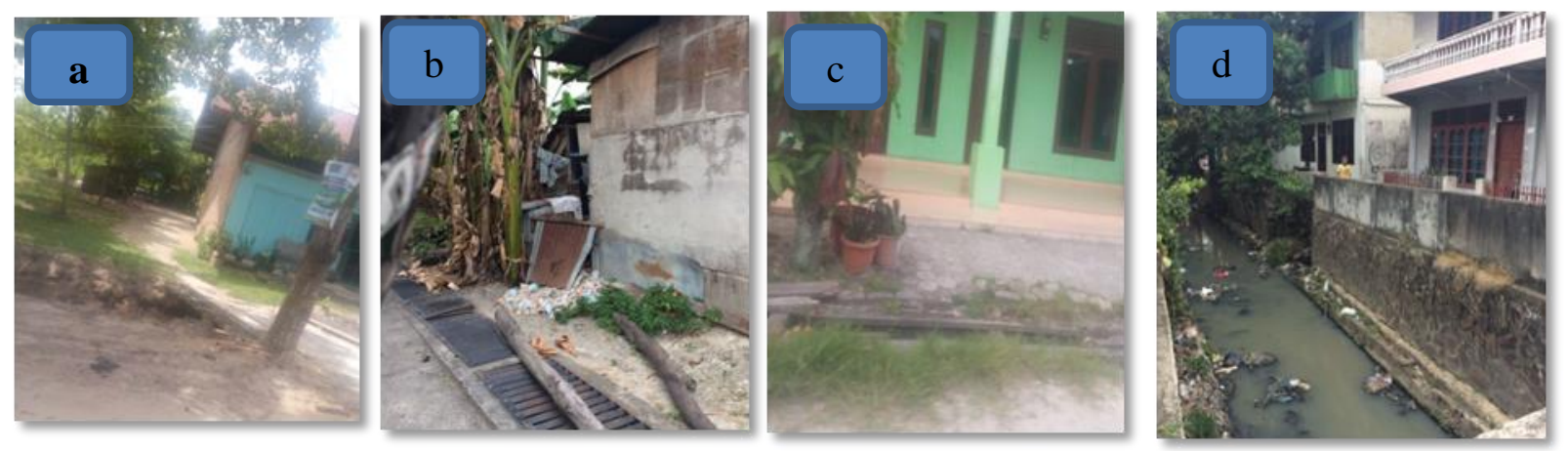

Gambar 7. Kondisi drainase lingkungan di beberapa kelurahan a. Drainase tidak permanen, b.Drainase yang terlalu kecil, c. Drainase permanen yang tidak terawat, d. Drainase yang dangkal dan ditumpuki oleh sampah.

Hasil wawancara kepada responden menunjukkan bahwa sebagian besar responden mengakui mempunyai drainse (parit/got) di permukimannya. Namun kondisi drainase yang ada masih banyak dengan kondisi kotor dan tidak terawat. Rumah tangga yang permukimannya memiliki drainase dengan kondisi bersih sebesar 48,00\%, permukiman yang memiliki drainase namun kondisinya kotor sebesar 42,00\%. Permukiman yang tidak ada drainase sebanyak 10,00\% (Gambar 8).

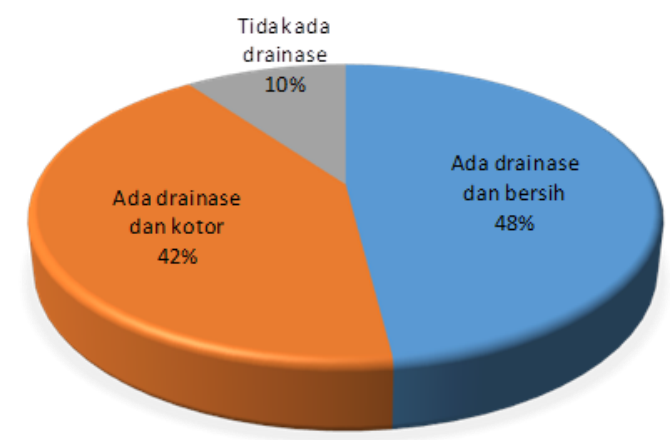

Gambar 8. Keberadaan dan kondisi drainase (parit) di permukiman responden

Keadaan ini diperparah dengan kurangnya kegiatan pembersihan drainase yang ada. Pembersihan drainase dilakukan warga tidak rutin yakni tergantung keadaan drainase/parit kotor. Hasil wawancara kepada responden didapat bahwa kegiatan pembersihan drainase/parit yang dilakukan rutin satu minggu sekali sebesar $17,78 \%$, kurang dari satu bulan sekali $16,67 \%$ dan dilakukan 2-3 minggu sekali sebesar $4,44 \%$. Sedang kegiatan yang terbesar dilakukan kadang-kadang tergantung got/parit kotor dan apabila hujan terjadi penyumbatan di saluran drainase tersebut yakni $61,11 \%$ (Gambar 9). Menurut Scott et al. (2014) habitat lalat umumnya pada tempat yang kotor seperti tempat pembuangan sampah. Lalat berkembang biak pada media berupa tinja atau feses, karkas, sampah, limbah buangan (Sigit et al., 2006) dan paling banyak pada kotoran hewan (Arroyo \& Capinera, 2008).

Kondisi lingkungan yang dapat menarik tikus yaitu adanya sampah yang terbuka. Lingkungan rumah yang kotor lebih banyak ditemukan hama tikus dari pada rumah yang bersih (Himsworth et al., 2013). Menurut Gomez et al. (2008) kelimpahan tikus di kota Rio Cuarto cenderung meningkat terdapat di kawasan yang kotor dan kumuh. Sementara kecoa hidup di tempat kotor yang banyak terdapat sampah pohon dan bahan yang mengandung selulosa (Bell et al., 2007)

Frekuensi kegiatan pembersihan drainase/parit yang dilakukan oleh penghuni rumah memberikan pengaruh terhadap kondisi tingkat kebersihan drainase yang ada. Hasil uji Chi Square antara kondisi drainase permukiman dengan frekuensi kegiatan pembersihan 
yang dilakukan oleh penghuni rumah berpengaruh pada taraf $\mathrm{p}=0,00$ dengan koefisien Chi Square 24,78. Hasil ini menunjukkan bahwa ada hubungan yang sangat erat dengan frekuensi kegiatan pembersihan drainase/parit terhadap kondisi kebersihan drainase yang ada di permukimannya. Diduga semakin sering dilakukan pembersihan, maka kondisi drainase/parit semakin bersih.

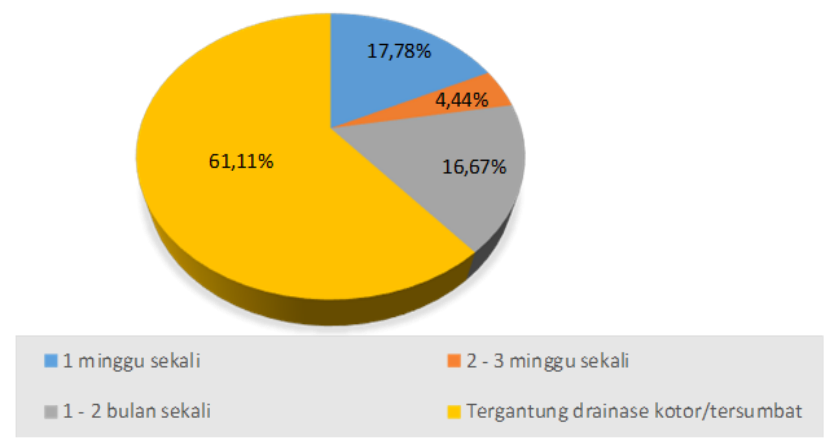

Gambar 9. Frekuensi kegiatan pembersihan drainase/parit di pemukiman warga

Fasilitas rumah yang harus tersedia agar permukiman sehat adalah ketersediaan tempat sampah. Hasil pengamatan langsung dan wawancara terhadap responden didapatkan bahwa sebagian besar rumah tangga memiliki tempat sampah di luar rumah $(72,28 \%)$ dan $27,72 \%$ yang tidak memiliki tempat sampah (Tabel 1). Sebagian besar rumah responden memiliki tempat sampah di luar rumah, kondisi tempat sampah yang ada tidak memiliki kelayakan sebagai tempat sampah, seperti menggunakan barang bekas, drum atau bak air yang bocor.

Tabel 1. Keberadaan tempat sampah di luar rumah

\begin{tabular}{llc}
\hline $\begin{array}{c}\text { Keberadaan } \\
\text { Tempat } \\
\text { Sampah }\end{array}$ & $\begin{array}{c}\text { Jumlah } \\
\text { Rumah } \\
\text { Tangga }\end{array}$ & Persentase (\%) \\
\hline Ada & 73 & 72,28 \\
Tidak Ada & 28 & 27,72 \\
\hline Jumlah & $\mathbf{1 0 1}$ & $\mathbf{1 0 0 , 0 0}$ \\
\hline
\end{tabular}

Pada rumah tangga yang tidak memiliki tempat sampah, penghuni rumah tangga memasukkan sampah di dalam kantong plastik lalu disangkutkan di pagar rumah, menunggu petugas kebersihan kecamatan/kelurahan mengambilnya. Bahkan ada yang ditumpukkan di halaman rumah dan dibakar (Gambar 10).
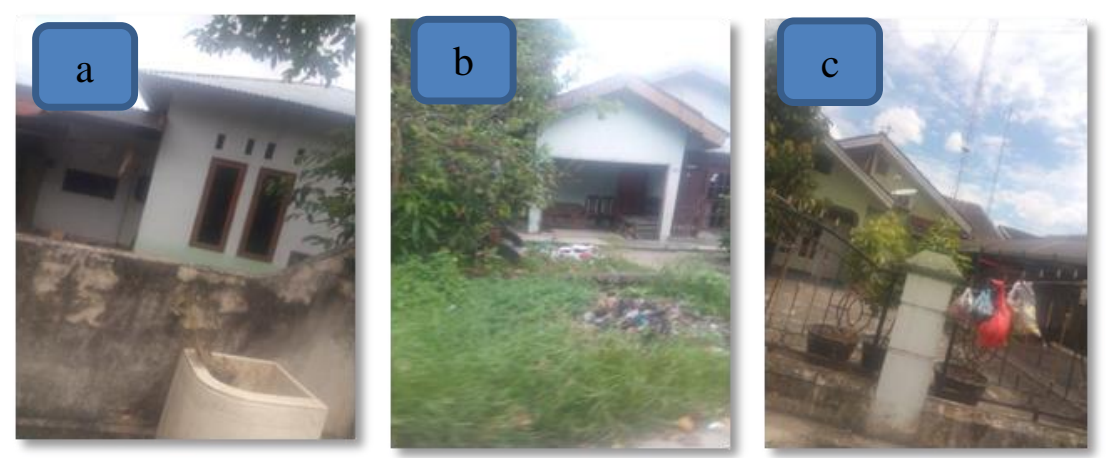

Gambar 10. Kondisi tempat pembuangan sampah di beberapa permukiman. a. Tempat sampah dengan pemanfaatan tong bekas b. Tidak memiliki tempat sampah c. Sampah dimasukkan dalam kantong plastic dan disangkut di pagar rumah

Upaya masyarakat pada permukiman lokasi penelitian dalam meningkatkan kebersihan lingkunganya dilakukan dengan melakukan gotong royong pembersihan lingkungan. Hasil survei didapat sebagian besar masyarakat (67,33\%) mengaku melakukan kegiatan gotong royong pembersihan lingkungan dan hanya $33,66 \%$ tidak pernah melakukan gotong royong.

Kegiatan gotong royong dilakukan masyarakat umumnya dilakukan tidak berkelanjutan tergantung dari kesepakatan warga permukiman. Hasil survei mendapatkan bahwa gotong royong yang dilakukan masyarakat tidak berkelanjutan (bersifat kadangkadang tergantung kesepakatan warga) sebanyak $59,78 \%$. Masyarakat yang melakukan gotong royong berkelanjutan setiap 1 bulan sekali sebanyak $27,17 \%$, kurang dari 2 bulan dan 1 minggu sekali masingmasing sebesar 6,52\% (Gambar 11).

Masyarakat mengaku belum adanya program rutin dan terencana dari pemerintah setempat dalam kegiatan gotong royong, baik dari kecamatan, kelurahan hingga RT. Kegiatan pembersihan lingkungan lebih rutin dilakukan oleh masing-masing anggota rumah tangga bila merasa kawasan pemukiman rumahnya kotor.

Hasil uji Chi Square menunjukkan bahwa keberadaan dan kondisi drainase/parit berhubungan erat dengan frekuensi kegiatan gotong pembersihan lingkungan yang dilakukan masyarakat. Hubungan erat tersebut pada taraf 0,028 dengan koefisien Chi Square 14,12. Hasil ini menunjukkan bahwa kegiatan gotong royong pembersihan lingkungan rumah berpengaruh terhadap kondisi kebersihan drainase/parit yang ada di permukiman tempat tinggal. Semakin sering gotong royong dilakukan oleh masyarakat, maka semakin bersih kondisi darinase/parit yang ada dipermukimannya. 


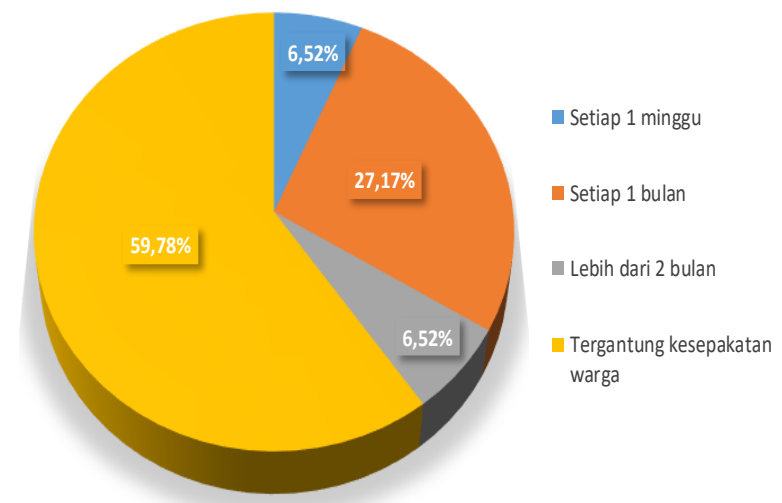

Gambar 11. Frekuensi kegiatan gotong royong pembersihan lingkungan yang dilakukan oleh masyarakat

Perilaku masyarakat membuang sampah pada tempatnya juga merupakan faktor yang mempengaruhi tingkat kebersihan lingkungan permukiman. Responden umumnya membuang sampah dari dalam rumah ke tempat sampah sementara di luar rumah dilakukan setiap hari $(60,47 \%), 2-3$ hari sebanyak $31,40 \%$ dan lebih dari 4 hari membuang sampah ke luar rumah sebanyak 8,14\% (Gambar 12).

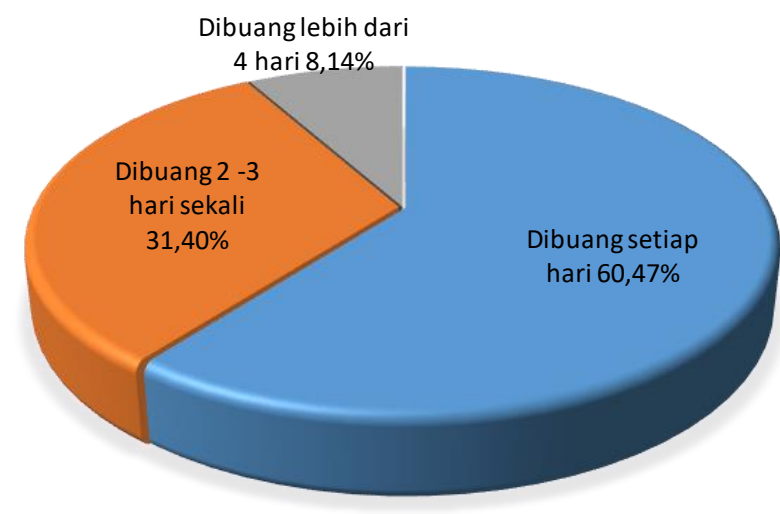

Gambar 12. Frekuensi sampah rumah tangga dibuang di tempat sampah sementara (luar rumah)

Hasil survei dan wawancara kepada responden menunjukkan sebagian besar sampahsampah tersebut tidak diangkut oleh petugas kebersihan $(55,68 \%)$ dan hanya $44,32 \%$ yang diangkut (Gambar 13). Kondisi ini mengakibatkan sampah menumpuk dalam waktu yang lama di tempat sampah sementara. Sampah yang menumpuk tersebut menjadi sumber munculnya hama terutama lalat, lipas dan tikus. Selain itu menebarkan bau yang kurang sedap. Menurut Nafis (2009) tempat yang disukai oleh hama untuk dijadikan sarang diantaranya kamar tidur, kamar mandi, dapur, tempat sampah, selokan dan halaman rumah yang kotor.

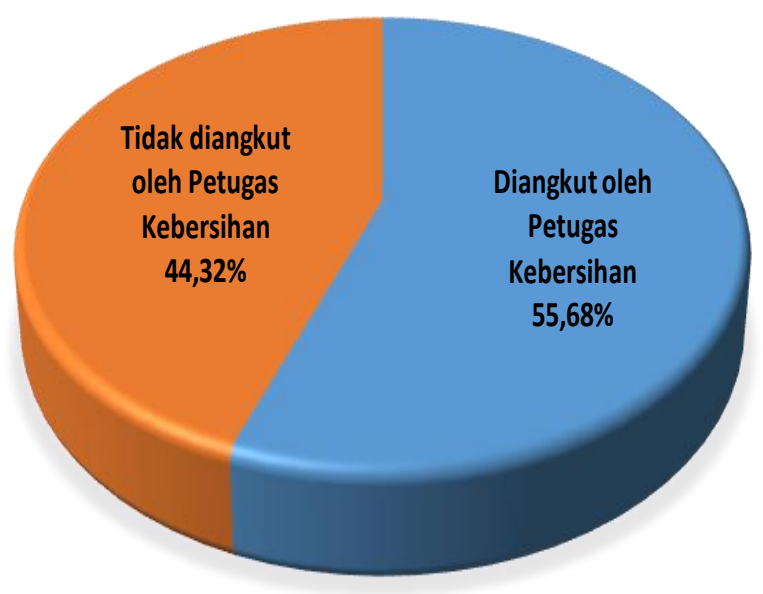

Gambar 13.Proporsi pengelolaan sampah oleh petugas kebersihan terhadap sampah rumah tangga dari tempat sampah sementara.

Menurut responden kewajiban pengangkutan sampah dari tempat sementara dari rumah mereka merupakan tanggungjawab Pemerintah Kota Pekanbaru melalui Dinas Kebersihan dan Pertanaman, Kecamatan dan Kelurahan. Hasil uji Chi Square menunjukkan bahwa ada hubungan antara pengangkutan sampah oleh petugas kebersihan dengan kondisi drainase/parit di sekitar permukiman. Tingkat keeratan hubungannya pada taraf 0,049 dengan koefisien Chi Square 5,84.

Selain itu, sampah-sampah yang ditumpukkan di luar rumah oleh masyarakat sebagian besar tidak diangkut oleh petugas kebersihan kecamatan, sehingga sampah menumpuk dalam jangka waktu yang cukup lama. Keadaan ini yang menyebabkan menumpuknya sampah di sekitar permukiman yang dapat menyebabkan munculnya hama permukiman seperti lalat, kecoa dan tikus. Selain itu, menyebabkan bau yang tidak sedap.

Kondisi drainase yang kotor dan tergenang juga merupakan habitat dari lalat, kecoa, tikus dan nyamuk. Bangunan yang tidak tertata dengan baik dan tanaman pekarangan berupa tanaman hias maupun tanaman peneduh yang tidak terawat memperburuk iklim mikro (suhu, kelembaban dan intensitas cahaya) rumah, sehingga rumah dan pekarangan dijadikan sebagai tempat tinggal, sembunyi dan laluan bagi hama. Menurut Buczkowski (2014), bahwa faktor lingkungan yaitu fisik dan biotik permukiman mempengaruhi keberadaan hama.

Menurut Scott et al. (2014); Speight (2008) \& Sigit et al. (2006) bahwa sumber munculnya hama permukiman berasal dari sampah rumah tangga dan lingkungan dalam rumah tidak tertata dengan baik. Menurut Nafis (2009), penyebab timbulnya hama permukiman diantaranya adalah sisa makanan, sampah, lingkungan yang kotor dan selokan. Lingkungan permukimn yang bersih merupakan habitat yang tidak cocok bagi hama permukiman 
sebagai tempat tinggal, bersembunyi dan berkembang biak (Speight, 2008).

Menurut Samways (1996) \& Koehler (2013) bahwa hama permukiman dapat dikendalikan dengan sanitasi lingkungan rumah dan luar rumah, dan melalui modifikasi habitat atau rekayasa lingkungan yang umumnya dengan cara perbaikan praktik sanitasi (Koehler, 2013).

\section{SIMPULAN}

Faktor lingkungan fisik permukiman rumah yang mempengaruhi keberadaan hama permukiman adalah lingkungan kotor yang disebabkan sampah dan drainase/parit kotor. Sedangkan faktor lingkungan biotik permukiman rumah yang mempengaruhi keberadaaan hama adalah tanaman yang ditanam di permukiman rumah berupa tanaman hias dan tanaman peneduh tidak terawat.

Keadaan lingkungan permukiman yang kotor tersebut disebabkan kurangnya kegiatan pembersihan lingkungan dan belum rutin pengangkutan sampah dari permukiman rumah ke tempat pembuangan akhir sampah. Selain itu kurang dilakukan perawatan terhadap tanaman hias dan peneduh di pekarangan rumah seperti dengan pemangkasan.

\section{UCAPAN TERIMA KASIH}

Penulis mengucapkan terima kasih kepada Debi Kurnia, SP., M.Si. dan Rahmat Syahputra, SP., M.Si. yang telah membantu suvei dan pengambilan sampel.

\section{DAFTAR PUSTAKA}

Arroyo, H.S., \& Capinera, J.L. (2008). House Fly Musca domestica Linnaeus (Insecta: Diptera: Muscidae). EENY-48, University of Florida. http://entnemdept.ufl.edu/creatures/urban/flies/h ouse_fly.HTM. Diakses 26 Nopember 2016.

BAPPEDA (Badan Perencanaan Pembangunan Daerah) Kota Pekanbaru. (2015). Informasi Kota Pekanbaru tahun 2015. Badan Perencanaan Pembangunan Daerah (BAPPEDA) Kota Pekanbaru, Pekanbaru.

Bell, W.J., Louis, M.R., \& Nalepa, C.A. (2007). Cockroaches: Ecology, Behavior, and Natural History. Johns Hopkins University Press, Baltimore.

Buczkowski, G. (2014). Urban pest management: The need for a correct mixture of knowledge and practice. In Urban Insect Pests-Sustainable Management Strategies, ist ed.; Dhang, P. (Ed.). CAB International: Oxfordshire, UK.

Dingha, B., Jackai, L., Monteverdi, R.H., \& Ibrahim, J. (2013). Pest control practices for the German Cockroach (Blattodea: Blattellidae): a survey of rural residents in North Carolina. Florida Entomologist. 96(3):1009-1015.

Farooq, U., Joshi, M., Nookala, V., Cheriyath, P., Fischman, D., Graber, N. J., Stellman, S. D., \& Muscat, J. (2010). Self-reported exposure to pesticides in residential settings and risk of breast cancer: a case-control study. Environ-mental Health. 9(30): 1-9.

Gomez, M. D., Cecilia, P. M.,\& Polop, J. J. (2008). Effect of interspecific compe-tition on Mus musculus in an urban area. Journal of Pest Science. 81 (4): $235-240$

Grossman, J. (1995). What's hiding under the sink: dangers of household pesticides. Environ Health Perspect. 103(6):550-4.

Guha, N., Ward, M. H., Gunier, R., Colt, J. S., Lea, C. S., Buffler, P. A., \& Metayer, C. (2013). Characterization of residential pesticide use and chemical formulations through self-report and household inventory: the Northern California childhood leukemia study. Environmental Health Perspectives. 121(2):276-282.

Himsworth, C.G., Feng, A. Y. T., Parsons, K., Kerr, T., \& Patrick, D. M. (2013). Using experiential knowledge to understand urban rat ecology: A survey of Canadian pest control professionals. Urban Ecosyst. 16:341-350.

Kardinan, A. (2007). Potensi selasih sebagai repellent terhadap nyamuk Aedes aegypti. Jurnal Penelitian Tanaman Industri. 13(2): 39-42

(2005). Daya proteksi zodia terhadap nyamuk Aedes aegypti. Jurnal Ilmiah Pertanian Gakuryoku. 11(1): 49-53

(2000). Pestisida Nabati, Ramuan dan Aplikasi. Cetakan ke-2. Penebar Swadaya, Jakarta.

Kass, D.E., McKelvey, W., Wye, G. V., Kerker, B., Mostashari, F., \& Eisenhower, D. (2005). Pests Can be Controlled Safely. NYC Vital Signs. 4(3):14.

Koehler, P.G. (2013). Urban Pests and Pest Management. This document is SP486A (IN1073), one of a series of the Entomology and Nematology Department, UF/IFAS Extension at http://edis.ifas.ufl.edu. The Institute of Food and Agricultural Sciences (IFAS).

Laksham K. B., Vinothkumar, K., Parthibane, S., Murthy, S. P., Arunachalam M. K., \& Chinnakali, P. (2016). Household biocide use and personal safety practices among rural population in South India: a community-based study. Česká a Slovenská Neurologie a Neurochirurgie. 79 (1):599-604.

Mavi, H.S., \& Tupper, G. J. (2004). Agrometeorology: Principles and Applications of Climate Studies in Agriculture. Food Products Press, New York.

Nafis, F. (2009). Persepsi masyarakat perkotaan terhadap hama permukiman serta pengujian perangkap dan pestisida untuk mengendalikan tikus dan kecoa. Thesis. Sekolah Pascasarjana Institut Pertanian Bogor, Bogor.

Oka, I.N. (2005). Pengendalian hama terpadu dan implementasinya di Indonesia. Gadjah Mada University Press. Yogyakarta.

Raini, M. (2009). Toksikologi Insektisida Rumah Tangga dan Pencegahan Keracunan. Media Penelit. dan Pengembang. Kesehat. 14(Suplemen II). Balitbang Departemen Kesehatan RI, Jakarta. 
Samways, M.J. (1996). Insects in the Urban Environment: Pest Pressures Versus Conservation Concern. In Wildey, K.B. (editor). Proceedings of the Second International Conference on Urban Pests.

Scott, J. G., Warren, W. C., Beukeboom, L. W., Bopp, D., Clark, A. G., Giers, S. D., Hediger, M., Jones, A. K., Kasai, S., Leichter, C. A., Li, M., Meisel, R. P., Minx, P., Murphy, T. D., Nelson, D. R., Reid, W. R., Rinkevich, F. D., Robertson, H. M., Sackton, T. B., Sattelle, D. B., ThibaudNissen, F., Tomlinson, C., van de Zande, L., Walden, K. K., Wilson, R. K., \& Liu, N. (2014). Genome of the house fly, Musca domestica L., a global vector of diseases with adaptations to a septic environment. Genome Biol.15(10): 466;1-16.

Singarimbun, M., dan Effendi. (2006). Metode Penelitian Survey. LP3ES, Jakarta.

Sigit, H.S., Koesharto, F. X., Hadi, U. K., Gunandini, D. J., dan Soviana, S. (2006). Hama Pemukiman Indonesia, Penge-nalan, Biologi dan Pengendalian. Unit Kajian Pengendalian Hama Permu-kiman (UKPHP), Fakultas Kedokteran Hewan IPB. Bogor.

Speight, M.R., Hunter, M. D., \& Watt, A. D. (2008). Ecology of Insects: Consepts and Application. The Alden Press, Britain.
Sutikno, A., Saputra, R., Rasyad, A., Amin, B., \& Mahatma, R. (2020). The Behavior of People at Pekanbaru City Indonesia in the Use of Household Pesticides to Control Pest of Settlement. J. Phys.: Conf. Ser. 1655 012101. DOI:10.1088/17426596/1655/1/012101

Sutikno, A., Rasyad, A., Amin, A., \& Mahatma, R. (2020). Persepsi Masyarakat Kota Pekanbaru Tehadap Gangguan Hama Permukiman. JIP. 16(28):1-9. - (2019a). Use of pesticides for household pest control in Pekanbaru City . Poll Res. 38 (4): 885889.

(2019b). The Perception of the Pekanbaru City resident on household pesticides. J. Phys.: Conf. Ser. $\quad 1351 \quad 012106 . \quad$ DOI:10.1088/17426596/1351/1/012106.

Untung (2006) \& Oka (2005) WHO (World Health Organization). (1999). Safe and effective use of household insecticide products. Geneva: World Health Organization. New York.

Yuliani, T. S. (2012). Perilaku penggunaan pestisida oleh ibu rumah tangga di wilayah DKI Jakarta. Disertasi. Sekolah Pasca-sarjana Instititut Pertanian Bogot, Bogor. 